\title{
Civil Construction Residue Management on Public Constructions in Barra do Garças City - Brazil
}

\author{
Marcela Magalhães Cabral ${ }^{1}$, Greyce Bernardes de Mello Rezende ${ }^{1}$, Raul Tadeu Lobato Ferreira ${ }^{1}$, \\ Vinicius Borges de Moura Aquino ${ }^{2}$, André Luis Christoforo ${ }^{2, *}$, Francisco Antonio Rocco Lahr ${ }^{3}$ \\ ${ }^{1}$ Earth and Exacts Sciences Institute (ICET), Federal University of Mato Grosso, Barra do Garças, Mato Grosso, Brazil \\ ${ }^{2}$ Department of Civil Engineering (DECiv), Federal University of São Carlos (UFSCar), São Carlos, Brazil \\ ${ }^{3}$ Department of Structural Engineering (SET), University of Sao Paulo, São Carlos, Brazil
}

\begin{abstract}
The increasing solid residue generation throughout the years, with the civil construction industry being responsible for most of this production, causes serious environmental impacts, since major part of this residue are not discarded appropriately. In this context, the present study intended to analyze the residue management on some public constructions of Barra do Garças City Hall, Brazilian state of Mato Grosso. For the analysis, it was carried out a checklist with 29 questions about waste management, based on Brazilian CONAMA Resolution 307/2002. Positive results were obtained for cleaning and organization on construction site and negative results for segregation residues and their destination. Also, a estimate of CCR production on some constructions and the costs to implement and operate a residue recycling plant in Barra do Garças city. Suggestions for CCR management improvement on construction site were made.
\end{abstract}

Keywords Recycling plant, Residue management, Segregation, Quantification, CCR

\section{Introduction}

It is well known by mankind the increasing generation of solid residue in the last years, with most of this residue coming from civil construction industry. The industry accounts for around $15 \%$ of the Brazilian GDP [1] and although it is an activity of great importance and with high economic potential, it has significant environmental impacts. According to Costa [2], waste generation occurs in all phases of an enterprise, from construction, renovation to the demolition phase of a structure. The type of residue generated depends on the constructive process adopted, being more common in residential constructions, residues of wood, concrete, metals, drywall, brick, roofing and others [3].

In several times, this residue is displaced in inappropriate places and with no treatment, contributing with environmental degradation and harming population healthcare [4].

In this context, considering the civil construction residue (CCR), many solutions have been searched to minimize this problem, among them, the reduction of residue generation,

* Corresponding author:

alchristoforo@gmail.com (André Luis Christoforo)

Published online at http://journal.sapub.org/ijme

Copyright $\odot 2018$ The Author(s). Published by Scientific \& Academic Publishing This work is licensed under the Creative Commons Attribution International License (CC BY). http://creativecommons.org/licenses/by/4.0/ reuse and recycling. Many materials, when separated and with appropriated destination, can be reused in the construction site or be recycled, originating a new product or feedstock.

In addition, there are a a number of strategies that can be used to reduce waste generation, such as standardization of design, stock control to minimize over ordering, and environmental education to workforce. The importance of the planning of each stage of the project is also emphasized, in order to avoid wastage of materials during the execution of the work [5].

Then, this research brings an analysis on how the civil construction residue management is performed in some public constructions of the Brazilian city of Barra do Garças, Mato Grosso state, pointing the pros and cons and the main faults according the Resolution 307/2002 of Environmental National Council (CONAMA) [6] and the Brazilian Law 12.305/2010 [7], which establishes the guidelines for solid residue management and the National Policy of Solid Residue, respectively.

Besides, for further economic viability study, an evaluation of implementation and operation costs of a rubble recycling plant was done. Therefore, many construction sites were visited aiming to collect data and information for the study following a checklist of CCR management and an estimative of residue production.

Also, this study presents a diagnosis about how the companies which executed public constructions in Barra do 
Garças city performs the CCR management and points solutions for the correct management of solid residue.

\section{Methodology}

The present research classifies itself as a quantitative and as case study, due to numerical samples which could quantify the CCR production in construction site and evaluate the necessary costs to establish the CCR recycling plant, the type of solid residue, residue production and construction site organization.

\subsection{Study Area}

Among Barra do Garças city public constructions, it were prioritized the reforms and enlargement constructions, well as constructions with considerable CCR production. In Figure 1, it is located the constructions sites (CS).

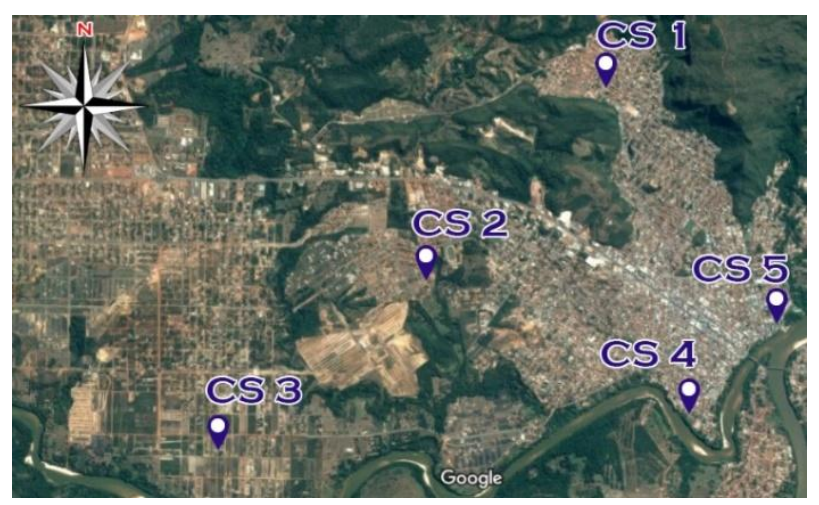

Figure 1. Construction Site localization on Barra do Garças city, Mato Grosso state

In Table 1 is disposed the characterization of five constructions. The visit and analysis of these constructions were performed between August and December, 2017.

Table 1. Construction Characterization

\begin{tabular}{|c|c|c|c|c|}
\hline Construction & $\begin{array}{c}\text { Area } \\
\left(\mathbf{m}^{2}\right)\end{array}$ & Localization & $\begin{array}{c}\text { Construction } \\
\text { phases }\end{array}$ & Employees \\
\hline 1 & 1029.88 & $\begin{array}{c}\text { Jardim } \\
\text { Araguaia }\end{array}$ & $\begin{array}{l}\text { Masonry } \\
\text { rising }\end{array}$ & 5 \\
\hline 2 & 1514.30 & Solar Ville & $\begin{array}{c}\text { Masonry } \\
\text { rising }\end{array}$ & 4 \\
\hline 3 & 1575.00 & Nova Barra & $\begin{array}{l}\text { Masonry } \\
\text { rising }\end{array}$ & 8 \\
\hline 4 & 340.29 & $\begin{array}{c}\text { São } \\
\text { Benedito }\end{array}$ & Finishing & 4 \\
\hline 5 & 704.96 & $\begin{array}{c}\text { Jardim } \\
\text { Mariano }\end{array}$ & $\begin{array}{c}\text { Demolition } \\
\text { and masonry } \\
\text { beginning }\end{array}$ & 12 \\
\hline
\end{tabular}

It is important to point out that construction execution is made by outsourced companies, contracted by bidding process and the city infrastructure secretary only inspect the constructions checking the deadline, budget and construction quality.

\subsection{Material and Methods}

Considering the data and information survey, the study was divided in four stages.

It is emphasized the importance of evaluation of what is done on each construction according the residue management to propose suggestions of improvements, allowing the comparison of residue use and construction productivity, in consequence, the impact in the final cost of construction.

\subsubsection{Stage 1}

Stage 1 aims to estimate the amount of CCR produced in some reforms and enlargement constructions of Barra do Garças City Hall. Thus, the estimation of CCR was made according the Nagalli method [1], beyond the data survey of dump bucket volume withdrawn from construction during a determinate period.

Nagalli method [1] establishes a relation between several factors of construction process as workforce, materials and schedule, disposed in Equation 1.

$$
X=\frac{K_{e} \cdot K_{p}^{2} \cdot K_{f} \cdot K_{c}}{\left(K_{e}+K_{f}+K_{c}\right)^{2}} \cdot Q \cdot T+S
$$

Being,

$\mathrm{X}$ : Estimated quantity for each type of residue;

$\mathrm{K}_{\mathrm{e}}$ : Number of people in workforce;

$\mathrm{K}_{\mathrm{p}}$ : Type of constructive process which will be adopted;

$\mathrm{K}_{\mathrm{f}}$ : Rigor in work inspection;

$\mathrm{K}_{\mathrm{c}}$ : Risk of schedule delay;

Q: Reference moisture adopted to quantify the residue;

T: Residue frequency;

S: Residue associated to material leftover

All coefficients used in Equation 1 are presented in following tables.

Table 2. $\mathrm{K}_{\mathrm{e}}$ Coefficients

\begin{tabular}{ccc}
\hline Experience and Training & Workforce Size & $\mathbf{K}_{\mathbf{e}}$ \\
\hline \multirow{2}{*}{ Untrained or few trained } & Less than Necessary & 1.5 \\
& Necessary & 1.3 \\
& More than Necessary & 1.2 \\
\hline Experient and/or trained & Necessary & 0.9 \\
& More than Necessary & 0.7 \\
\hline
\end{tabular}

The coefficient $\mathrm{K}_{\mathrm{p}}$ can be determined by the type of constructive process or by the amount of wastage, according Tables 3 and 4 .

The critical path cited in Table 6 refers to the sequence of activities which produces the longest time, determining the full schedule of the project [8]. 
Table 3. $\mathrm{K}_{\mathrm{p}}$ Coefficients (Constructive Process)

\begin{tabular}{ccc}
\hline Constructive Process & $\mathbf{K}_{\mathbf{p}}$ \\
\hline Masonry with Ceramic Blocks & 1.15 \\
Masonry with Concrete Blocks & 1.0 \\
Masonry with Soil-Cement Blocks & 1.5 \\
Wood Siding & 2.0 \\
Metallic Siding & 0.8 \\
Gypsum Plaster Lining & 1.5 \\
Glass & 0.05 \\
\hline Table 4. $\mathrm{K}_{\mathrm{p}}$ Coefficients (Wastage) & \\
\hline Wastage & $\mathbf{K}_{\mathbf{p}}$ & \\
\hline $2 \%$ & 0.1 & \\
$4 \%$ & 0.5 & \\
$10 \%$ & 1.15 & \\
$15 \%$ & 1.65 & \\
$20 \%$ & 2.1 & \\
$30 \%$ & 3.2 & \\
$40 \%$ & 4.4 \\
$50 \%$ & 6.0 \\
$80 \%$ & 6.5 \\
$100 \%$ & 52 \\
\hline
\end{tabular}

Table 5. $\mathrm{K}_{\mathrm{f}}$ Coefficients

\begin{tabular}{cc}
\hline Frequency in inspection & $\mathbf{K}_{\mathbf{f}}$ \\
\hline None & 1.4 \\
Rarely & 1.1 \\
Regular & 1.1 \\
Permanent & 1.5 \\
\hline
\end{tabular}

Table 6. $\mathrm{K}_{\mathrm{c}}$ Coefficients

\begin{tabular}{cc}
\hline Schedule Flexibility & $\mathbf{K}_{\mathbf{c}}$ \\
\hline Flexible and long schedule, activities in critical path & 1.2 \\
Flexible and long schedule, activities out the critical path & 1.1 \\
Short-term activities, in the critical path & 1.1 \\
Short-term activities, in the critical path & 1.0 \\
\hline
\end{tabular}

These coefficients were calculated based on the observation of the residue amount produced in several constructions. The use of this method is advantageous because, according Nagalli [1], it is possible to compatible the workforce and management of a building company, allowing the extension the behavior pattern for all the others constructions from the building company.

Besides, in this stage it was calculated the losses index (IP). Souza [9] describes the amount of material theoretically necessary as function of the quantity of products generated by the service. Then, there is following equation:

$$
Q M T=Q S \cdot \frac{Q M}{Q S} \cdot \frac{Q M S}{Q M}
$$

Being:

QMT: Amount of material theoretically necessary;
QS: Amount of services executed;

QMS: Amount of material simply demanded

Expressing the losses index (IP) as percentage:

$$
I P(\%)=\frac{Q M R-Q M T}{Q M T} .100
$$

Where QMR refers to the amount really necessary.

It is necessary mention the IP is an estimation, based in the quantity of material theoretically necessary, calculated according the project. Analyze the percentage of losses allows to realize where are the problems e improve the materials use and reduce the wastage.

\subsubsection{Stage 2}

Stage 2 intended to evaluate how construction companies deals with CCR on each construction. Then, a checklist was elaborated to verify the CCR management. The checklist contained 29 questions about CCR, treating themes as construction site organization, transportation and packaging, destination, residue reuse and recycling, legislation and inspection and ecological practices adopted by construction companies.

The data obtained with the checklist will be presented through graphics with the percentage of "yes" and "no" referent to each topic, permitting evaluate the CCR management adopted in the studied constructions.

\subsubsection{Stage 3}

Stage 3 consisted in visiting construction sites to analyze their organization and the actions performed by construction companies when treating the CCR management. Beyond that, suggest improvements to reduce residue quantity and obtain a better use of generated residue.

\subsubsection{Stage 4}

Stage 4 it was carried out a implementation and operation cost gathering of a recycling CCR plant, which initially would meet three of five studied constructions, due their large CCR production.

Considering the amount of CCR produced per day on each construction, obtained with residue bucket volume, and the cost composition in the SINAPI Table (11/2016), it was possible to estimate the cost of residue transportation to the crushing plant, choose the appropriate machine for the demand and the necessary workforce to operate the machines. The SINAPI table used is a reference system of costs for urban constructions, in which the price of inputs is published monthly for all the brazilian capitals and for the Federal District [10].

Also, it was necessary to estimate the indirect cost, which are the energy consumption, according the operation time, the EPIs (Individual Protection Equipment), which must be provided by the construction companies and the costs of the construction of temporary installations. 


\section{Results and Discussion}

\subsection{Quantification of Produced Residue}

The quantification of residue was made in two manners. The first, an estimate of production of ceramic masonry residue based in the Nagalli method [1] and the second, a quantification based in the dump bucket volume withdrawn from construction sites.

Due to lack of some relevant data, the estimate from Nagalli formula [1] was carried out for only two constructions and the results are disposed:

\section{- Construction 1}

Ceramic Masonry Residue

Masonry Area: $534.6 \mathrm{~m}^{2}$

Block Quantity: 20314.8 un

Block Especification: 14x19x09 cm

Material Volume: 20314.8 x 0.14 x 0.19 x $0.09=48.63 \mathrm{~m}^{3}$

Calculation of the S parameter - Admitting the purchase of $5 \%$ extra material to fulfill unexpected losses and $20 \%$ of the material will become residue by the construction end [1].

$$
\begin{gathered}
\mathrm{S}=0.05 \times 0.2 \times 48.63 \\
\mathrm{~S}=0.4863 \mathrm{~m}^{3}
\end{gathered}
$$

Admitting $\mathrm{T}=1$, by cause of residue is generated only once in construction [7].

The coefficients are:

$\mathrm{K}_{\mathrm{e}}=0.9$ (experient workforce)

$\mathrm{K}_{\mathrm{p}}=1.15$ (ceramic masonry)

$\mathrm{K}_{\mathrm{f}}=1.1$ (regular inspection)

$\mathrm{K}_{\mathrm{c}}=1.2$ (activities in critical path)

Substituting the coefficients in Eq. 1, the estimate masonry residue is $4.52 \mathrm{~m}^{3}$, only.

- Construction 2

Ceramic Masonry Residue

Masonry Area: $1475.56 \mathrm{~m}^{2}$

Block Especification: $14 \times 19 \times 09 \mathrm{~cm}$

Block Quantity: 56071.28 un

Material Volume: 56071.28 x 0.14 x 0.19 x $0.09=134.24$ $\mathrm{m}^{3}$

Calculation of the S parameter - Admitting the purchase of $5 \%$ extra material to fulfill unexpected losses and $20 \%$ of the material will become residue by the construction end [1].

$$
\begin{gathered}
\mathrm{S}=0.05 \times 0.2 \times 134.24 \\
\mathrm{~S}=1.34 \mathrm{~m}^{3}
\end{gathered}
$$

Admitting $\mathrm{T}=1$, by cause of residue is generated only once in construction [1].

The coefficients are:

$\mathrm{K}_{\mathrm{e}}=0.9$ (experient workforce)

$\mathrm{K}_{\mathrm{p}}=1.15$ (ceramic masonry)

$\mathrm{K}_{\mathrm{f}}=1.1$ (regular inspection)

$\mathrm{K}_{\mathrm{c}}=1.2$ (activities in critical path)

Substituting the coefficients in Eq. 1, the estimate masonry residue is $12.48 \mathrm{~m}^{3}$, only.
The quantification through dump bucket volume was made for three of five analyzed construction, by reason of the other constructions had an advanced schedule. The amounts are disposed in Table 7.

Table 7. $\mathrm{K}_{\mathrm{c}}$ Coefficients

\begin{tabular}{ccc}
\hline Construction & Period (months) & Volume $\left(\mathbf{m}^{\mathbf{3}}\right)$ \\
\hline 1 & 5 & 18 \\
2 & 5 & 54 \\
3 & 3 & 85 \\
\hline
\end{tabular}

In this way, the constructions were monitored and the number of dump buckets and residue trucks was counted, being three dump buckets of $6 \mathrm{~m}^{3}$ for construction 1 , nine dump buckets of $6 \mathrm{~m}^{3}$ for construction 2 and for construction 3 , there were seven dump buckets of $5 \mathrm{~m}^{3}$ and five trucks of $10 \mathrm{~m}^{3}$.

Analyzing the amount of CCR generated by the constructions and comparing the obtained results through the Nagalli method [1], which considered only the residue coming from ceramic masonry, and the results obtained by the quantification of the dump bucket volume, the ceramic masonry residue represent around $25 \%$ of construction 1 residue and $23 \%$ of construction 2 residue.

It is important to highlight that, in practice, for these constructions, the amount of masonry residue is higher than the estimate obtained by Nagalli method, considering this result only the residue produced by new masonry, disregarding the residue coming from demolition of the old masonry. Hence, the difference between estimate and the quantification of volume of dump bucket.

About construction 3, it is observed the amount of residue higher than the other constructions. It occurs due to the fact of larger building area and the most of residue comes from demolition, meanwhile the others constructions had a minor percentage of demolition. Considering, on average, 59\% of residue provides from reforms, demolitions and enlargement construction [7], in the analyzed constructions it were observed a percentage of $65 \%$ originated of these type of construction (Construction 1 and 3).

\subsubsection{Calculation of Losses Index}

The calculation of losses index was done for masonry through Eq. 2 and 3. The calculus are presented next.

- Construction 1

QS: $438.41 \mathrm{~m}^{2}$ (Corresponding to masonry area, discounting doors and windows areas)

QM: $39.88 \mathrm{~m}^{3}$ (Necessary Block Volume)

QMS: 16659.58 (Demanded Block Quantity)

Substituting the values on Eq. 2:

$\mathrm{QMT}=438.41 \times(39.88 / 438.41) \times(16659.58 / 39.88)=$ 16659.58

Expressing the losses in percentage:

$\operatorname{IP}(\%)=(20314.8-16659.58) / 16659.58 \times 100=21.94$ 
- Construction 2

QS: $1298.1 \mathrm{~m}^{2}$ (Corresponding to masonry area, discounting doors and windows areas)

QM: $118.1 \mathrm{~m}^{3}$ (Necessary Block Volume)

QMS: 49327.61 (Demanded Block Quantity)

Substituting the values on Eq. 2:

$\mathrm{QMT}=1298.1 \times(118.1 / 1298.1) \times(49327.61 / 118.1)=$ 49327.61

Expressing the losses in percentage:

$\operatorname{IP}(\%)=(56071.28-49327.61) / 49327.61 \times 100=13.6$

Then, it is estimated that construction 1 has approximately $21.94 \%$ of masonry losses and construction 2 has $13.6 \%$ masonry losses. In this context, it can be compared with data presented by other authors as Formoso et al. [11], who evaluated an average value analyzing more than twenty construction companies in Brazilian state of Rio Grande do Sul, obtaining an IP of $20.6 \%$ for masonry losses and John and Agopyan [12], who presents data obtained through 52 construction companies across Brazil, obtaining an IP of $13 \%$ for masonry losses.

Observing the estimated IP for construction 1, it is close to the average obtained by construction companies in Brazilian state of Rio Grande do Sul and the estimated IP for construction 2 is closer to the Brazilian average IP. According Formoso et. al. [11], this variation on IP is common, by cause of similar construction sites may present different IP for each type of material, as John and Agopyan [12] demonstrated this variability occurs even in construction companies using the same technology. Then, it is demonstrated the possibility of loss reduction only performing changes on project management, materials, tools and workforce training.

\subsection{CCR Management in Constructions}

\section{- Construction 1}

This construction is a reform and enlargement of a child day care. During the visit, it was observed a considerable production of residue. Considering the fact this construction has been accompanied since the beginning, a large quantity of wood residue used for formwork was found in the site.

Also, during the construction period, some changes in project, which resulted in the masonry demolition already built, producing block and grout residue. The engineer in chief used part of this residue to embank part of the ground with no structural function.

The steel residue have been reused in own construction or taken to another construction executed by the constructions company. The cement bags (Figure 2) were separated for discard, as the ink cans.

The construction site was cleaned regularly to avoid material accumulation and all the unused residue was withdrawn on dump buckets. The material storage was made appropriately, avoiding damages and losses.

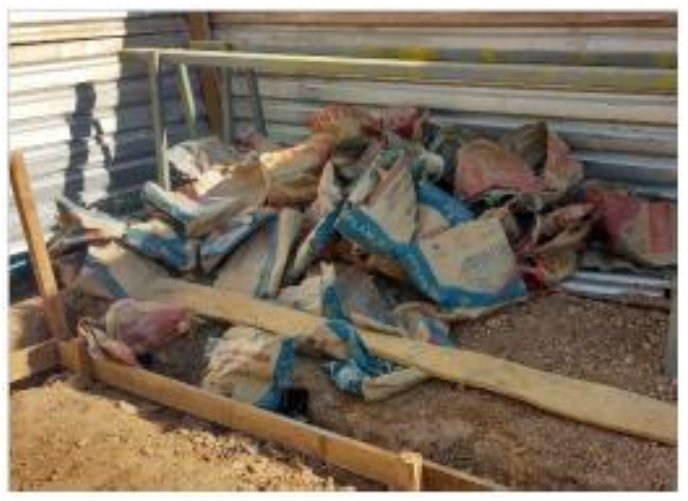

Figure 2. Cement bags - Construction 1

- Construction 2

This is a new construction in a large area, being possible to observe several strategies used by the foreman aiming the least production of residue.

In the construction site, showed in Figure 3, there was no accumulation of residue, and according the responsible, the cleaning is made day to day, claiming the work in an organized side improves the productivity and reduce the risk of accidents.

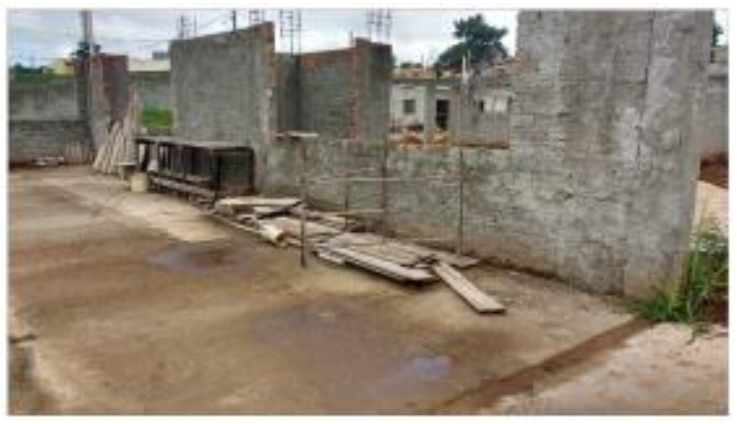

Figure 3. Construction Site - Construction 2

Considering the masonry residue, there were almost none, due to use of two sizes of block, avoiding their break and loss (Figure 4).

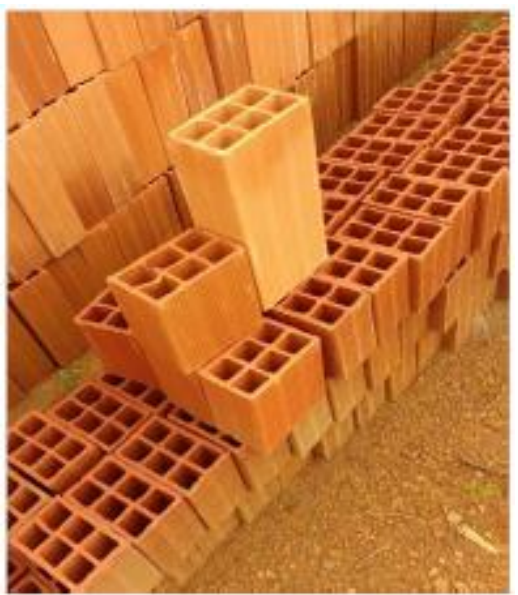

Figure 4. Two sizes of blocks - Construction 4 
The steel residue was reused in own construction site for confection of stirrups and tools to sustain the armor on reinforced concrete during the concreting, keeping in the correct site (Figure 5).

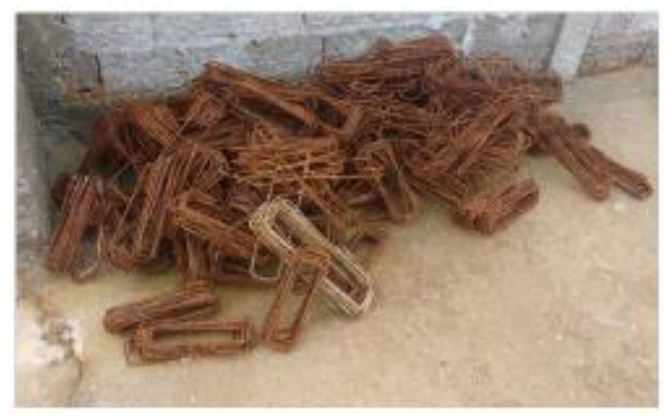

Figure 5. Steel used in the stirrups confection

And the wood residue was used as formwork for beam and column concreting.

\section{- Construction 3}

Also a new construction (Figure 6) and has been executed by the construction company of Construction 2 . Therefore, the same characteristics and strategies used to reduce the residue and the construction site organization were observed, although this construction has an advanced schedule, when comparing with the anterior.

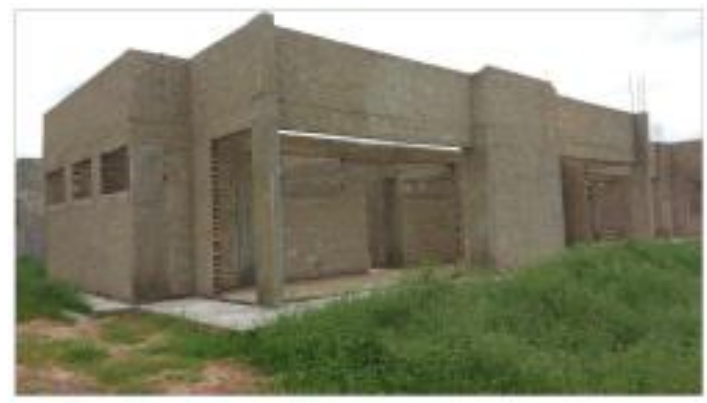

Figure 6. Construction Site - Construction 3

\section{- Construction 4}

This construction was made by the same company of the two previous constructions, being possible to observe the pattern in the material use, enhancing their use, producing the minimum waste possible. This construction is on finishing phase (Figure 7).

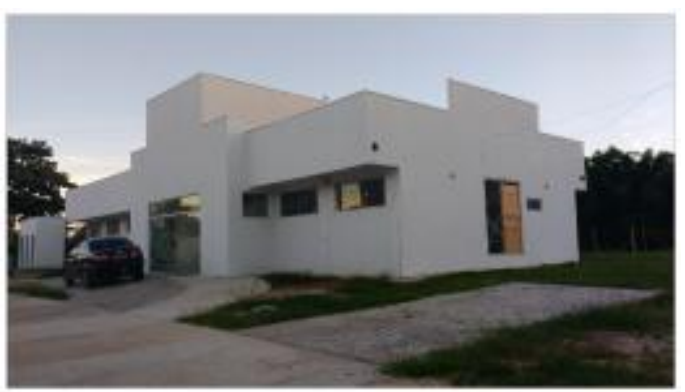

Figure 7. Construction on final phase - Construction 4

\section{- Construction 5}

This is a reform and enlargement construction, with a great generation of residue. During the visits, it was possible to observe several types of residues, since steel, masonry, wood and ink cans (Figure 8).

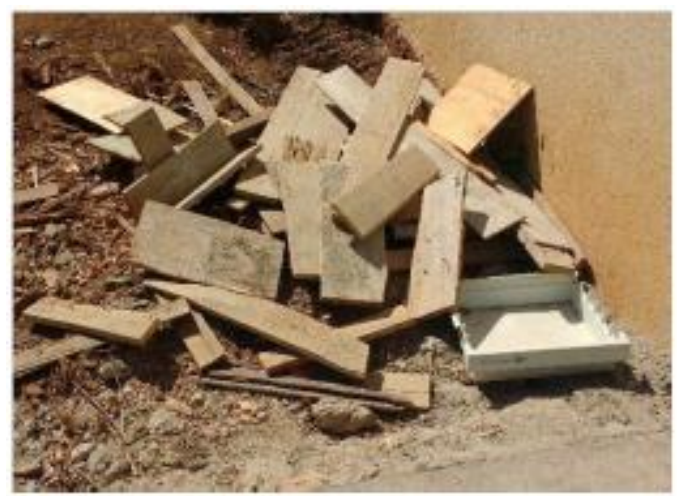

Figure 8. Wood residue

Common to all studied construction sites, the perception of cleaning concern on the site was present, but any reuse or recycling actions were adopted.

As disposed on Figure 9, the residues were separated on the site to be withdrawn by the dump bucket company, but the appropriate destination according the material classes was not executed.

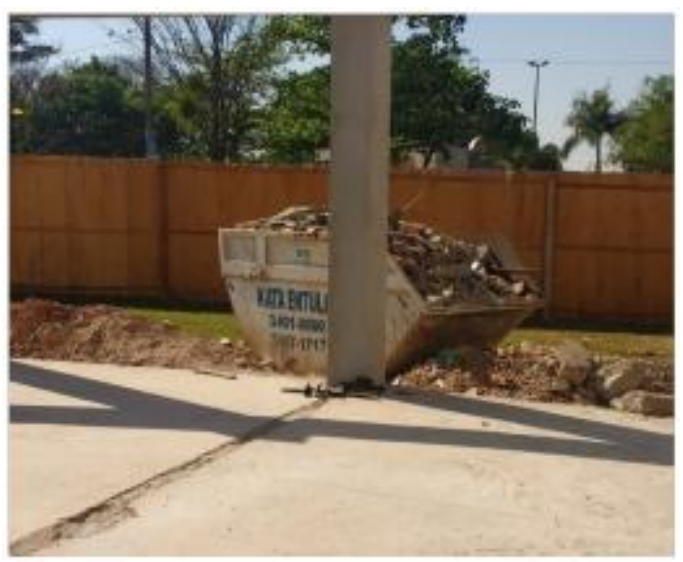

Figure 9. Dump bucket - Construction 5

Briefly, after all construction visits, some common factors were detected and with some simple changes by the part of companies could achieve a better productivity and reach the environmental laws.

As described, most of the residues do not receive the appropriate process of segregation or receive the correct destination. Thus, many materials, which could be reused or recycled, suffer damages, bringing losses to the company and risk of accidents for workforce.

The adoption of some measures could solve these problems, using silos to store the materials in a safe way and separate according their class, using recycled materials and aware the workforce for a better use of materials. 


\subsection{Analysis of CCR Management Observed on Constructions}

With the applied checklist, it was possible to obtain some information and have an wide view about CCR management in the studied constructions. For a better understanding, the results are divided by topics, with the percentage of "YES" and "NO".

\subsubsection{Construction Site Organization}

In relation to construction site organization, there were observed several initiative taken by the companies to keep up the site cleaned, on conditions to provide a better productivity, avoiding the waste accumulation.

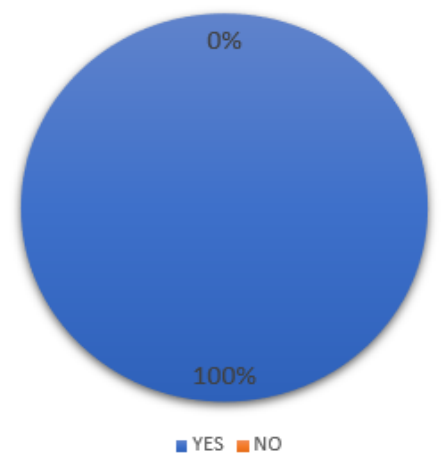

Figure 10. Construction site organization

As observed on Figure 10, all visited constructions there is the concern to not allow residues on the site, claiming it could bring risk of accident to workforce and harm the construction schedule.

Then, among all topics studied, this was the only which presented such a positive result, since an organized site increases productivity, due to application of efficient process and no obstruction caused by material accumulation.

\subsubsection{Transportation and Storage}

In this topic, it was evaluated how the storage and transportation of material is made on the site, aiming the separation of the residues considering their classes and the correct packaging, avoiding harm a material which could be reused.

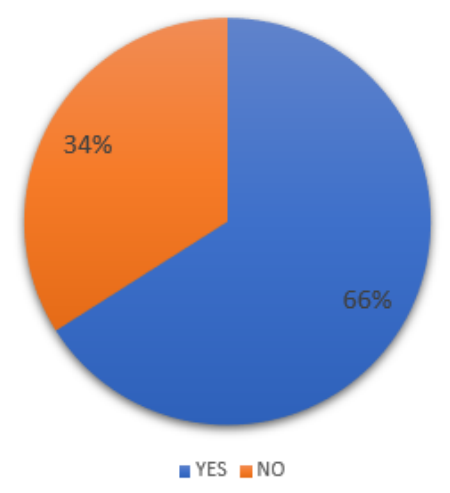

Figure 11. Transportation and Storage
In this question, as shown by Figure 11, it was observed that most of constructions aimed to store and transport correctly the materials on site, dodging their deterioration, however the residues were not segregated and stored appropriately based on their class, according the CONAMA Resolution 307/2002 (and further alterations) [6].

Considering the dangerous residues, as ink and solvent residues, any type of transportation or packaging was observed on sites. The empty cans, according the Brazilian Law 12305/2010 [7], must return to manufacture industry, in reverse logistic system, for treatment of ink residues [7].

\subsubsection{Residue Destination}

This topic treats questions about properly destination of residues, following the CONAMA Resolution 307/2002 [7], according the material class and the use of dump buckets (Figure 12).

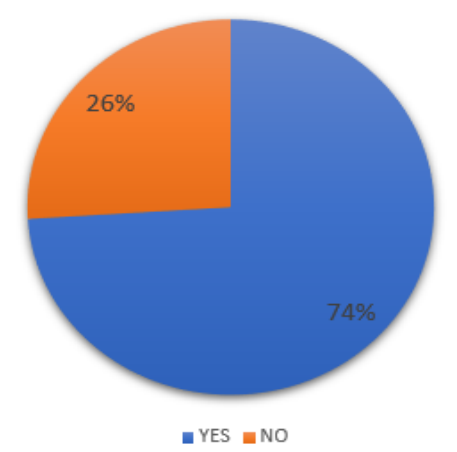

Figure 12. Residue destination

About the residue destination, in most of constructions did not concerned to perform a properly destination for each type of material following the material class, displacing all residues in the same place, regardless of material.

Referring to dump buckets use offered by certified companies, only two constructions did not used this service due to their low production of residues.

\subsubsection{Reuse and Recycling}

This item deals with questions of residue production control made by companies, well as recycling and reuse of residues in own construction and workforce awarding for residue separation following material class (Figure 13).

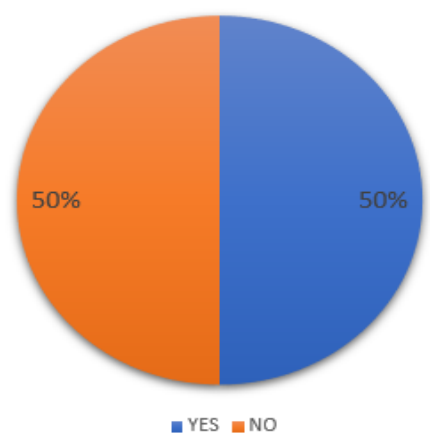

Figure 13. Reusing and Recycling 
It was checked that all constructions possessed a residue production control, but they did not applied separation and recycling methods on construction site. A positive point verified in this topic was the material reusing, with most of constructions did reuse of some material on construction, reducing the amount of generated residue.

\subsubsection{Legislation and Inspection}

This topic refers to the elaboration of Civil Construction Residue Management Plan, demanded by CONAMA Resolution 307/2002 [6], construction inspection by public authorities and the orientation of City Hall about the CCR destination (Figure 14).

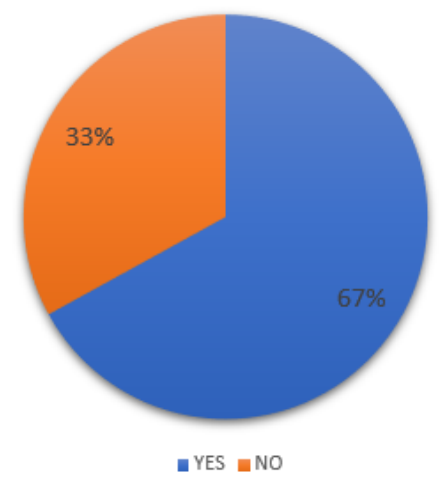

Figure 14. Legislation and Inspection

Despite the fact of all constructions have been inspected by City Hall authorities, it was not verified the Civil Construction Residue Management Plan by the companies and any concern of City Hall authorities about a properly CCR destination.

\subsubsection{Conscious Ecological Practices}

This item cites questions about using recycled material in construction, practices which aims residues amount and packaging collection by suppliers (Figure 15).

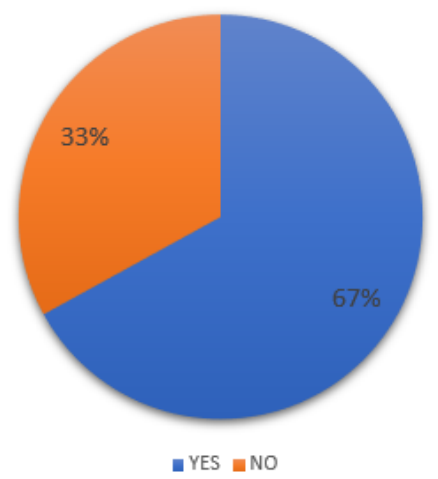

Figure 15. Conscious ecological practices

Most of visited constructions have adopted any type of practice intending to improve the materials use, reduce losses and residue production. Nonetheless, neither packaging collection by suppliers was not observed nor recycled products use.

Therefore, the results obtained are very alarming, since the major part of topics displayed negative results. Analyzing all results, it can be inferred the few actions taken by companies and public authorities about a properly CCR management, what harms environment by inappropriate displacement of the residues and companies, which could take advantage on the use of this residues.

Facing the disposed results, it must be highlighted the relevance of a residue recycling plant. In the next section it will be presented a cost estimation and a layout suggestion for a plant to attend Barra do Garças city demand.

\subsection{Costs of Implementation and Operation of a Residue Recycling Plant}

Aiming to evaluate the necessary costs for implementation and operation of a residue recycling plant, a data collection was made, considering the idea of this plant fulfill three of the studied constructions, with whole cost divided by them.

For this, the first step was the determination the quantity of residue produced by the constructions. This quantification considered the dump bucket volume withdrawn and it is demonstrated on Table 8 .

Table 8. Residue Quantification

\begin{tabular}{|c|c|c|c|}
\hline Construction & Period (month) & Volume $\left(\mathbf{m}^{\mathbf{3}}\right)$ & $\begin{array}{c}\text { Total } \\
\left(\mathbf{m}^{\mathbf{3}} / \mathbf{d a y}\right)\end{array}$ \\
\hline 1 & 5 & 18 & 0.12 \\
\hline 2 & 5 & 54 & 0.36 \\
\hline 5 & 3 & 85 & 0.94 \\
\hline \multicolumn{3}{|c|}{ TOTAL } & 1.42 \\
\hline
\end{tabular}

After the determination the quantity of residues generated by the constructions, it is possible to determine which will be the necessary initial investment, considering the adequate equipment to supply the demand, the design and data collection of installations as offices and restrooms, as disposed on Table 9.

After the budget analysis of several crushers and the expected demand, the most adequate was a mobile crusher, with a production capacity of 6 up to 8 tons per hour (Figure 16).

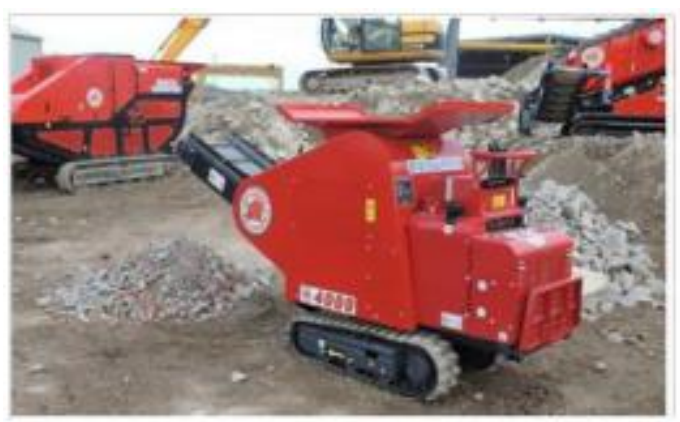

Figure 16. Mobile Crusher 
Table 9. Initial Investiment

\begin{tabular}{|c|c|c|c|c|}
\hline ITEM & Unit & Amount & Unitary Cost & Total \\
\hline Equipment & unit & 1 & $\mathrm{R} \$ 258,400.00$ & $\mathrm{R} \$ 258,400.00$ \\
\hline $\begin{array}{c}\text { Office in } \\
\text { masonry }\end{array}$ & $\mathrm{m}^{2}$ & 6,9 & $\mathrm{R} \$ 722.34$ & $\mathrm{R} \$ 4,984.15$ \\
\hline Restroom & $\mathrm{m}^{2}$ & 4,14 & $\mathrm{R} \$ 653.77$ & $\mathrm{R} \$ 2,706.61$ \\
\hline \multicolumn{5}{|c|}{ Total } \\
\hline
\end{tabular}

Besides the initial investment, there are the indirect costs, among them the costs of operation and employees, described on Tables 10 and 11. The equipment budget was executed by an specialized company on residue recycling plant machinery, and the other costs (workforce, loading and unloading, transportation to the plant) were estimated by the SINAPI Table (11/2016).

Table 10. Workforce costs

\begin{tabular}{|c|c|c|c|c|}
\hline $\begin{array}{c}\text { Number of } \\
\text { employees }\end{array}$ & Function & Quantity & Unit & $\begin{array}{c}\text { Income } \\
\text { per month) }\end{array}$ \\
\hline 1 & Secretary & 1 & month & $\mathrm{R} \$ 1,238.87$ \\
\hline 1 & Servant & 6 & $\begin{array}{c}\text { hours/ } \\
\text { day }\end{array}$ & $\mathrm{R} \$ 2,493.00$ \\
\hline 1 & Foreman & 1 & month & $\mathrm{R} \$ 3,535.98$ \\
\hline \multicolumn{5}{|c|}{ Total } \\
\hline
\end{tabular}

Among the operation cost, it is necessary to calculate current spending as water and energy bills. For the energy bill, it considered the operation for 6 hours a day, 20 days per month, considering the energy company rate of $\mathrm{R} \$ 0.42$ per kWH.

For estimate the water consumption on residue recycling process, according Jadovski apud Manfrinato [13], it is used the following relation:

Spending $=\mathrm{R} \$ / \mathrm{m}^{3}$ (water) $\times 0.08 \times$ total residue processed volume

The water company rate is $\mathrm{R} \$ 6.31$ per cubic meter for public services in Barra do Garças city.

Table 11. Operation costs

\begin{tabular}{|c|c|c|c|c|}
\hline ITEM & Unit & Quantity & $\begin{array}{c}\text { Unitary } \\
\text { Cost }\end{array}$ & Total/month \\
\hline $\begin{array}{l}\text { Loading and } \\
\text { Unloading }\end{array}$ & $\mathrm{m}^{3}$ & 1.42 & $\mathrm{R} \$ 0.94$ & $\mathrm{R} \$ 26.78$ \\
\hline $\begin{array}{l}\text { Transport to } \\
\text { the Central }\end{array}$ & $\mathrm{m}^{3}$ & 1.42 & $\mathrm{R} \$ 4.88$ & $\mathrm{R} \$ 139.03$ \\
\hline Water & $\mathrm{m}^{3}$ & 0.11 & $\mathrm{R} \$ 6.31$ & $\mathrm{R} \$ 14.38$ \\
\hline $\begin{array}{l}\text { Eletric } \\
\text { Energy }\end{array}$ & KWh & 52.2 & $\mathrm{R} \$ 0.42$ & $\mathrm{R} \$ 2,652.99$ \\
\hline EPI's & h/day & 6 & $\mathrm{R} \$ 0.88$ & $\mathrm{R} \$ 211.20$ \\
\hline \multicolumn{4}{|c|}{ Total } & $\mathrm{R} \$ 3,044.38$ \\
\hline
\end{tabular}

The total costs of implementation and operation of the plant are presented on Table 12.
Table 12. Total Costs of Implementation and Operation

\begin{tabular}{|c|c|c|}
\hline & Initial Investment & Expenses per month \\
\hline TOTAL & $\mathrm{R} \$ 266,090.75$ & $\mathrm{R} \$ 9,073.36$ \\
\hline
\end{tabular}

As presented, even being a small mobile equipment, their production capacity of aggregate is very large, being possible serve more constructions in the city, increasing the production and the possibility of commercialization of this recycled aggregate for construction companies.

\subsubsection{Plant Layout}

Considering the quantity of residue that this plant would supply, a layout suggestion was done, displaying a receiving, trial and recycling areas, and an area for recycled aggregate, also, the administrative area. Therefore, the city needed a area about $200 \mathrm{~m}^{2}$.

The layout was designed following the Brazilian Standard ABNT NBR 15155 [14], which brings the guidelines for the design, implementation and operation of civil construction solid residues recycling areas. Hence, the implementation area must obey the environmental legislation and accepted by the population.

Therefore, it is emphasized the recycling plant must optimize the process flow, since the material receiving to the recycled aggregate collection. And it ought to be considered the minimum impacts during the plant implementation and operation for environmental and for the neighborhood.

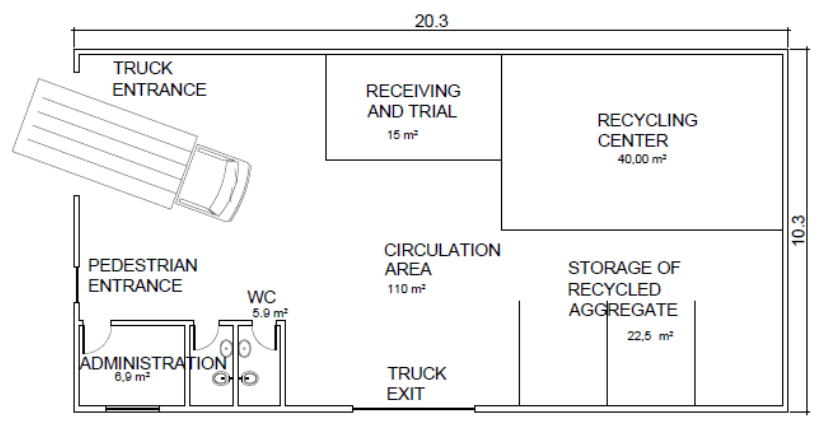

Figure 17. Plant Layout Suggestion

It is worth highlight this is an efficient layout which could be replicated for plants that serves a similar residue demand, supplied by small constructions and small production of residue.

\subsection{Improvement Suggestion Based on the Realized Diagnosis}

Based on constructions visits and the analysis of the applied checklist, there were several problems on construction sites as CCR management and final destination of CCR. Also, some positive actions taken by the companies will be pointed out.

Despite the construction inspection by public authorities, most of them disposed any concern about segregation and storage of CCR, minimizing the damages for further reusing. 
Still, due to lack of planning and some project changes occurred during the construction caused losses of material in some sites. Otherwise, other constructions used strategies to get rid of losses reduced the amount of produced waste, for example, the use of two sizes of blocks, avoiding block cracks and loss.

This way, this and other strategies could be used in every construction, which would reduce the produced residues. Part of construction losses occurs by cause of incorporated construction material on amounts higher than necessary. According John and Agopyan [12], these losses could be avoided through workforce training and a better management of constructive process.

In addition, the material reuse was also verified in the constructions as a form to cut down the residue generation, using masonry waste for embankment execution with no structural function, wood reuse for column and beam formwork on concreting and steel reuse for stirrups confection.

Another positive aspect observed on the constructions was the cleaning and organization on the site. All companies were concerned to keep up the site clean and organized, with no material accumulation, preventing accidents and improving the productivity.

In relation to CCR management, construction companies must separate the material residue handling the CONAMA Resolution 307/2002 [6] and the storage of this material should minimize damages enabling the reuse of some materials.

Considering the presented information, it is demonstrated the viability of a residue recycling plan implementation, since the reduction of material prices due to use of recycled aggregate, the commercialization of this aggregate for other companies a better use of the construction site, decreasing the area designated for waste displacement.

Beside the economic aspect, the plant implementation would benefit the population, reducing the risk of contamination and diseased proliferation caused by waste accumulation.

\section{Conclusions}

The present research permitted evaluate how the increase of solid residuum amount impacts society financially and harms environment. And it made possible investigate how CCR is treat by construction companies which works on public works.

Considering the importance of performing a better residue use, a data collection of costs was made for implementation and operation of a residue recycling plant, demonstrating how it could be used by companies, bringing changes in medium and long term on construction costs.

In general, the correct CCR management is not a priority for construction companies, whereas any construction presented the adequate residue segregation and destination, disposing the waste inappropriately.
Although, many constructions have embraced strategies to improve material utilization, reducing losses and producing less residues. The organization on construction site was present, with the consideration to maintain the site clean and organized.

This way, the need of public authorities inspect the CCR management rigidly is important and necessary.

Analyzing the recycling plant for CCR, for further researches is important to evaluate an economic viability analysis for the residue recycling plant implementation and operation which would serve more constructions in the city.

\section{ACKNOWLEDGMENTS}

For all the provided support, the authors thanks the Coordenação de Aperfeiçoamento de Nível Superior (CAPES) and the Conselho Nacional de Desenvolvimento Científico e Tecnológico (CNPq).

\section{REFERENCES}

[1] Nagalli, André. Gerenciamento de resíduos sólidos de construção civil. São Paulo: Oficina de textos, 2014.

[2] Costa, Ricardo Vasconcelos Gomes da. Taxa de geração de resíduos da construção civil em edificações na cidade de Jõao Pessoa. Master dissertation, UFPB/CT. João Pessoa, 2012.

[3] Lau, H.H. Whyte, A. Law, P.L. Composition and Characteristics of Construction Waste Generated by Residential Housing Project. Int. J. Environ. Res., 2(3): 261-268, Summer 2008.

[4] John, Vanderley M. Reciclagem de resíduos na construção civil: Contribuição para metodologia de pesquisa e desenvolvimento. São Paulo, 2000.

[5] A. A. Gulghane et al. Int. Journal of Engineering Research and Applications. Vol. 5, Issue 4, (Part -1) April 2015, pp.59-64.

[6] Ministério do Meio Ambiente. Resolução $n^{\circ}$ 307/2002: Estabelece diretrizes, critérios e procedimentos para a gestão dos resíduos da construção civil, 2002.

[7] Ministério do meio ambiente. Lei $\mathrm{n}^{\circ} 12$ 305, de 02 de agosto de 2010. Institui A Política Nacional de Resíduos Sólidos.

[8] Mattos, Aldo Dórea. Planejamento e controle de obras. São Paulo: Pini, 2010.

[9] Souza, Ubiraci Espinelli Lemes de. Como reduzir perdas nos canteiros: manual de gestão do consumo de materiais na construção civil. São Paulo: Pini, 2005.

[10] Caixa Econômica Federal. Manual de metodologias e conceitos do SINAPI. Available in: http://www.caixa.gov.br/ Downloads/Livro_SINAPI_Metodologias_e_Conceitos_vers ao_digital_4a_Edicao.pdf. Acess in: 07/15/2018.

[11] Formoso, et.al. Perdas na construção civil: conceitos, classificações e seu papel na melhoria do setor. Porto Alegre, p.01-11, 1997. Disponível em: (http://www6.ufrgs.br/norie/i 
ndicadores/de\%20cesare.pdf).

[12] John, v.m; agopyan, v. Reciclagem de resíduo da construção. São Paulo, 2000.

[13] Manfrinato, j. W. S.; esguícero, f. J.; martins, b. L. XXVIII Encontro Nacional de Engenharia de Produção: A integração de cadeias produtivas com a abordagem da manufatura sustentável, UNESP. Rio de Janeiro, 2008.
[14] Associação brasileira de normas técnicas (ABNT). NBR 15 114 - Resíduos sólidos da Construção civil - Áreas de reciclagem - Diretrizes para projeto, implantação e operação. Rio de Janeiro, 2004.

[15] Formoso, Carlos T. Lean construction: Princípios básicos e exemplos. 2002. Core oriented to the innovation of the building, Federal University of Rio Grande do Sul, Rio Grande do Sul, 2002. 